\title{
RANKING ŚWIATOWYCH SYSTEMÓW EMERYTALNYCH WEDŁUG MELBOURNE MERCER GLOBAL PENSION INDEX
}

Bożena Kołosowska

dr hab. prof. UMK, Katedra Zarządzania Finansami, UMK w Toruniu

\section{Wprowadzenie}

W wielu krajach na świecie wyzwania jakie stoją przed ich systemami emerytalnymi związane są ze starzeniem się społeczeństwa. Jest to niezależne od wpływów historycznych, politycznych, społecznych czy też ekonomicznych. Wszelkie reformy podejmowane w celu złagodzenia powstających skutków zachodzących zmian są podobne i dotyczą przede wszystkich wydłużania wieku emerytalnego, stałego opłacania składek na ubezpieczenia emerytalne, zachęcają do dłuższej pracy i długoterminowego oszczędzania na przyszłe świadczenia emerytalne.

Głównym celem postawionym w opracowaniu jest przedstawienie indeksu The Melbourne Mercer Global Pension Index (MMGPI) porównującego 27 systemów emerytalnych uwzględniając ponad 40 wskaźników. Brane są pod uwagę następujące obszary: alokacja aktywów funduszy emerytalnych, rozwiązania post-emerytalne na świecie, przejrzystość i zaufanie w systemach emerytalnych, stabilność systemów emerytalnych, skutki starzenia się społeczeństwa. Szczegółowo zaprezentowano ocenę polskiego i chilijskiego systemu emerytalnego. Pokazano zalecenia jakie postawiono przed rozwiązaniami wprowadzanymi przez rządzących w tychże krajach. 


\section{Powstanie niezależnego systemu oceny światowych systemów emerytalnych}

Według badań przeprowadzonych przez ONZ, w ostatnich latach znacząco zwiększyła się na świecie liczba osób starszych, a proces starzenia społeczeństwa ma się pogłębiać w najbliższych dziesięcioleciach. W 2015 r. liczba osób w wieku wyższym bądź równym 60 lat wynosiła na świecie 901 milionów. W stosunku do 2000 r. nastąpił przyrost osób starszych o 48\%. Prognozuje się, że liczba osób starszych na świecie w 2030 r. sięgnie 1,4 miliarda, a w 2050 r. 2,1 miliarda. Zwraca uwagę fakt, że przyrost liczby ludzi najstarszych (powyżej 80 lat) następuje szybciej, niż ogólny przyrost ludzi starszych (powyżej 60 lat). Raport pokazuje, iż liczba osób w wieku przekraczającym 80 lat potroi się w 2050 r. w stosunku do roku 2015 [World population ageing 2015, 2015: 9, dostęp: 13.01.2017]. Systemy emerytalne będą musiały sprostać tym nadchodzącym zmianom.

Głównym celem postawionym w opracowaniu było dokonanie przeglądu kompleksowej oceny systemów emerytalnych obejmujących prawie 60\% światowej populacji za lata 2009-2016. Polska jako jedyna z krajów Europy Środkowo-Wschodniej reprezentowana jest w tym rankingu. Liczony od 2009 roku Światowy Indeks Emerytalny - The Melbourne Mercer Global Pension Index (MMGPI) mierzy obecnie 27 systemów emerytalnych uwzględniając ponad 40 wskaźników. Brane są pod uwagę następujące obszary: alokacja aktywów funduszy emerytalnych, rozwiązania post-emerytalne na świecie, przejrzystość i zaufanie w systemach emerytalnych, stabilność systemów emerytalnych, skutki starzenia się społeczeństwa.

To co można zauważyć - firma Mercer silnie preferuje rozwiązania zwiększające wsparcie dla najbiedniejszych emerytów czy też skłaniające do podnoszenia oszczędności gospodarstw domowych [www1]. Duży nacisk kładzie się także na zwiększanie poziomu aktywności zawodowej w starszych grupach wiekowych [www2]. Bardzo wysoko cenione jest powiązanie wieku emerytalnego ze spodziewaną długością życia. W duńskim systemie emerytalnym to następuje, stąd też przewidywany wiek emerytalny w 2050 roku ma wynieść 69 lat [www8], co zostało wysoko docenione, stawiając ten system od wielu lat na pierwszym miejscu spośród 27 ocenianych systemów emerytalnych.

Dla każdego z krajów, dla których ustalany jest indeks w pierwszym kroku wyliczane są trzy, tak zwane wskaźniki cząstkowe. Następnie liczona jest $\mathrm{z}$ nich średnia ważona i to właśnie ten wynik daje całkowitą wartość indeksu. Określane są następujące czynniki korygujące, charakteryzujące: 
- adekwatność (40\% GPI),

- trwałość (35\% GPI),

- integralność (25\% GPI).

Adekwatność związana jest z zapewnieniem emerytom przyszłych świadczeń, co wydaje się być zasadniczym celem każdego systemu emerytalnego. Obejmuje ona: przewidywany poziom przyszłego dochodu, stopę zastąpienia netto dla osób osiągających średni dochód, świadczenia otrzymywane przez osoby o średnich i niskich dochodach, cechy konstrukcyjne i właściwości zwiększające skuteczność systemu emerytalnego.

Trwałość tworzą cechy, które decydują o zrównoważonym rozwoju danego systemu. Ocenia jego długoterminową stabilność. Obejmuje szereg wskaźników uwzględniających czynniki wpływające na trwałość systemu, a więc: starzenie się społeczeństwa, współczynnik aktywności zawodowej, wysokość długu publicznego, efektywność funkcjonowania prywatnych funduszy emerytalnych, finansowanie systemu, staże pracy dla emerytów.

Integralność obejmuje zaś trzy obszary oceny systemu emerytalnego: regulacje prawne i zarządzanie funduszami, ochronę i komunikację członków funduszy, ponoszone koszty. Istotne jest tutaj także zaufanie społeczeństwa do funduszy emerytalnych. W systemach emerytalnych zbliżonych do polskiego ważna jest współpraca publicznych i prywatnych sektorów części kapitałowej.

\begin{tabular}{|c|l|l|}
\hline Ocena & Wartość indeksu & \multicolumn{1}{c|}{ Opis } \\
\hline A & $>80$ & $\begin{array}{l}\text { System emerytalny niezawodny (stabilny), który dostarcza } \\
\text { wysokich świadczeń, samofinansujący się, ma wysoki poziom } \\
\text { integralności. }\end{array}$ \\
\hline $\begin{array}{c}\text { B+ } \\
\text { B }\end{array}$ & $\begin{array}{l}75-80 \\
65-75\end{array}$ & $\begin{array}{l}\text { System o solidnej konstrukcji, posiadający wiele dobrych cech, } \\
\text { jednak pewne obszary wymagają naprawy, nie pozwalające być } \\
\text { systemem grupy A. }\end{array}$ \\
\hline $\begin{array}{c}\text { C+ } \\
\text { Cysten }\end{array}$ & $\begin{array}{l}60-65 \\
50-60\end{array}$ & $\begin{array}{l}\text { System, który posiada pewne dobre cechy, obarczony jest przy } \\
\text { tym wysokim ryzykiem, i/lub innymi brakami, które muszą być } \\
\text { naprawione. Bez tych zmian utrzymanie niezawodności w dłu- } \\
\text { gim okresie staje pod znakiem zapytania. }\end{array}$ \\
\hline D & $35-50$ & $\begin{array}{l}\text { System, który ma pewne pożądane cechy, ale również duże sła- } \\
\text { bości, i/lub niedociágnięcia, które wymagają naprawy. Bez tych } \\
\text { działań efektywność i skuteczność staje pod znakiem zapytania. }\end{array}$ \\
\hline E & $<35$ & $\begin{array}{l}\text { Słaby system, który może być we wczesnych stadiach rozwoju } \\
\text { lub nieistniejący. }\end{array}$ \\
\hline
\end{tabular}

Tabela 1. Klasyfikacja punktowa systemów emerytalnych według The Melbourne Mercer Global Pension Index Źródło: www7 (dostęp: 17.11.2016). 


\begin{tabular}{|c|c|c|}
\hline Rok & Ocena & Kraje \\
\hline \multirow{5}{*}{2009} & A & - \\
\hline & $\mathrm{B}$ & Holandia, Australia, Szwecja, Kanada \\
\hline & $\mathrm{C}$ & Wlk. Brytania, USA, Chile, Singapur \\
\hline & $\mathrm{D}$ & Niemcy, Chiny, Japonia \\
\hline & $\mathrm{E}$ & - \\
\hline \multirow{5}{*}{2010} & A & - \\
\hline & B & Holandia, Szwajcaria, Australia, Szwecja, Kanada \\
\hline & C & Wlk. Brytania, USA, Chile, Singapur, Brazylia, Francja, Niemcy \\
\hline & $\mathrm{D}$ & Japonia, Chiny \\
\hline & $\mathrm{E}$ & - \\
\hline \multirow{7}{*}{2011} & A & - \\
\hline & $\mathrm{B}+$ & Holandia, Australia \\
\hline & B & Szwecja, Szwajcaria, Kanada, Wlk. Brytania \\
\hline & $\mathrm{C}+$ & Chile \\
\hline & C & Polska, Brazylia, USA, Singapur, Francja, Niemcy \\
\hline & $\mathrm{D}$ & Japonia, India, Chiny \\
\hline & $\mathrm{E}$ & - \\
\hline \multirow{7}{*}{2012} & A & Dania \\
\hline & $\mathrm{B}+$ & Holandia, Australia \\
\hline & $\mathrm{B}$ & Szwecja, Szwajcaria, Kanada \\
\hline & $\mathrm{C}+$ & Wlk. Brytania, Chile \\
\hline & C & Polska, Brazylia, USA, Singapur, Francja, Niemcy \\
\hline & $\mathrm{D}$ & Japonia, India, Chiny, Korea Poł. \\
\hline & $E$ & - \\
\hline \multirow{7}{*}{2013} & A & Dania \\
\hline & $\mathrm{B}+$ & Holandia, Australia \\
\hline & B & Szwajcaria, Szwecja, Kanada, Singapur, Chile, Wielka Brytania \\
\hline & $\mathrm{C}+$ & - \\
\hline & $\mathrm{C}$ & Niemcy, USA, Polska, Francja, Brazylia, Meksyk, \\
\hline & $\mathrm{D}$ & Chiny, Japonia, Korea Południowa, Indie, Indonezja \\
\hline & $E$ & - \\
\hline \multirow{7}{*}{2014} & A & Dania \\
\hline & $\mathrm{B}+$ & Australia, Holandia \\
\hline & B & Finlandia, Szwajcaria, Szwecja, Kanada, Chile, Wielka Brytania, Singapur \\
\hline & $\mathrm{C}+$ & Niemcy, Irlandia \\
\hline & $\mathrm{C}$ & USA, Francja, Polska, RPA, Austria, Brazylia \\
\hline & $\mathrm{D}$ & Włochy, Meksyk, Chiny, Indonezja, Japonia, Korea Południowa, Indie \\
\hline & $\mathrm{E}$ & - \\
\hline \multirow{6}{*}{2015} & A & Dania, Holandia \\
\hline & $\mathrm{B}+$ & Australia \\
\hline & B & Finlandia, Szwecja, Szwajcaria, Singapur, Kanada, Chile \\
\hline & $\mathrm{C}+$ & Irlandia, Wielka Brytania \\
\hline & C & Niemcy, USA, Francja, Malezja, Brazylia, Polska, Austria \\
\hline & D & $\begin{array}{l}\text { Włochy, RPA, Indonezja, Korea Południowa, Chiny, Meksyk, Indie, Japonia, } \\
\text { Argentyna }\end{array}$ \\
\hline \multirow{7}{*}{2016} & A & Dania, Holandia \\
\hline & $\mathrm{B}+$ & Australia \\
\hline & B & Finlandia, Szwecja, Szwajcaria, Singapur, Kanada, Chile \\
\hline & $\mathrm{C}+$ & Trlandia, Wielka Brytania \\
\hline & C & Niemcy, USA, Francja, Malezja, Brazylia, Polska, Austria \\
\hline & D & $\begin{array}{l}\text { Włochy, RPA, Indonezja, Korea Południowa, Chiny, Meksyk, Indie, Japonia, } \\
\text { Argentyna }\end{array}$ \\
\hline & $\mathrm{E}$ & - \\
\hline
\end{tabular}

Tabela 2. Ocena systemów emerytalnych w latach 2009-2016 według The Melbourne Mercer Global Pension Index

Źródło: www7 (dostęp: 17.11.2016); Raporty MMGPI z lat 2009-2016. 
W raportach dotyczących GPI pokazywana jest ogólna wartość indeksu dla każdego kraju, wraz z wartością indeksu dla każdego z trzech wskaźników cząstkowych: adekwatności, stabilności i integralności. Każda wartość indeksu oznacza ocenę od 0 do 100. Przypisana ocena od A do E wskazuje na cechy systemów emerytalnych należących do danej klasy. Do klasy najwyżej ocenianej, jako A - należą systemy o stabilnych podstawach finansowych, gwarantujące wysoki poziom świadczeń, o stabilnych regulacjach prawnych. Przez okres trzech pierwszych lat prowadzonej klasyfikacji żaden $z$ ocenianych systemów emerytalnych nie otrzymał oceny A. Także w całym okresie, w którym publikowane są raporty żadnemu systemowi nie przypisano oceny najniższej - E. Ukazano to w tab. 1.

Prezentację rankingu systemów emerytalnych 11 krajów rozpoczęto w 2009 roku, żaden system nie dostał w tym roku, a także przez dalsze trzy lata najwyższej (czy też najniższej) oceny. Systematycznie wzrasta liczba ocenianych systemów emerytalnych wybranych krajów na świecie, w 2016 roku było ich 27. W 2012 roku rozpoczęto klasyfikować system emerytalny Danii, który jako pierwszy otrzymał najwyższą ocenę A, którą utrzymuje już piąty rok. Do niej dołączyła w 2015 roku Holandia. Od 2011 roku wprowadzono dodatkowe oceny: $\mathrm{B}+$ oraz $\mathrm{C}+$. Systematycznie wzrastała także liczba krajów, których systemy emerytalne podlegają ocenie. Prezentuje to tab. 2.

W 2009 roku ocenie podlegały systemy emerytalne jedenastu krajów, rok później doszły cztery kraje: Szwajcaria, Brazylia, Francja. W 2011 roku zaczęto oceniać system emerytalny Polski oraz Indii. Dalsze zmiany zachodzące w liczbie systemów emerytalnych podlegających rankingowi prezentuje tab. 3 .

\begin{tabular}{|c|c|l|}
\hline Rok & $\begin{array}{c}\text { Liczba krajów } \\
\text { podlegających } \\
\text { ocenie }\end{array}$ & \multicolumn{1}{|c|}{ Nowy kraj, którego system emerytalny podlega ocenie } \\
\hline 2009 & 11 & $\begin{array}{l}\text { Holandia, Australia, Szwecja, Kanada, Wlk. Brytania, USA, Chile, } \\
\text { Singapur, Niemcy, Chiny, Japonia }\end{array}$ \\
\hline 2010 & 14 & Szwajcaria, Brazylia, Francja \\
\hline 2011 & 16 & Polska, Indie \\
\hline 2012 & 18 & Dania, Korea Płd. \\
\hline 2013 & 20 & Meksyk, Indonezja \\
\hline 2014 & 25 & Finlandia, Irlandia, RPA, Austria, Włochy \\
\hline 2015 & 27 & Malezja, Argentyna \\
\hline 2016 & 27 & - \\
\hline
\end{tabular}

Tabela 3. Kraje wchodzące do systemu ocen w poszczególnych latach według The Melbourne Mercer Global Pension Index Źródło: opracowanie własne na podstawie danych z tab. 2.

W ostatnich dwóch latach ocenianych jest 27 systemów emerytalnych wybranych krajów świata, obejmujących $60 \%$ światowej populacji. Ranking pozwala promować te rozwiązania, które stanowią o adekwatności, 
stabilności, trwałości krajowych systemów emerytalnych. Dodatkowo należy zwrócić uwagę na fakt, iż określa jednocześnie działania naprawcze, których podjęcie może pomóc w utrzymaniu pozytywnych cech w wyznaczonych obszarach.

\section{Polski system emerytalny w rankingu firmy Mercer}

Polska jako jedyna z krajów Europy Środkowo-Wschodniej reprezentowana jest $\mathrm{w}$ rankingu ukazującym kompleksowe porównanie systemów emerytalnych obejmujących prawie $60 \%$ światowej populacji. Polski system emerytalny rozpoczęto oceniać od 2011 roku z przyznaną klasą C, która do ostatniego roku oceny, czyli do 2016 roku jest utrzymywana. Co oznacza, iż nasz system posiada pewne dobre cechy, lecz obarczony jest przy tym wysokim ryzykiem, i/lub innymi brakami, które muszą być naprawione. Bez tych zmian utrzymanie niezawodności w długim okresie staje pod znakiem zapytania.

W przygotowanym przez polski oddział Mercera raporcie dotyczącym wybranych aspektów polskiego systemu emerytalnego, szczególną uwagę zwrócono na funkcjonowanie Otwartych Funduszy Emerytalnych. Negatywnie oceniono stopniowe ograniczanie znaczenia części kapitałowej naszego systemu. Na świecie obserwuje się szerszą marginalizację „Bismarcowskich” systemów repartycyjnych [Holzmann 2012]. Ponadto dostrzeżono ryzyko związane $\mathrm{z}$ wywiązywaniem się przez ZUS ze swoich zobowiązań, wysokość wynagrodzeń i kosztów powszechnych towarzystw emerytalnych, a także niestabilność prawa z uwzględnieniem wpływu zmian legislacyjnych na funkcjonowanie towarzystw emerytalnych [Mercer rekomenduje..., 2016; Nowak i Sucharski 2015]. Obawy o niewywiązywanie się z zobowiązań emerytalnych związane są z: niskim poziomem aktywów emerytalnych, wysoką wartością istniejących i przyszłych zobowiązań, obecnym deficytem i rosnącą dotacją do FUS, poziomem zadłużenia państwa oraz pogarszającą się sytuacją demograficzną polskiego społeczeństwa.

Przychody FUS przyjmują stałą już tendencję w kolejnych latach: maleją przychody ze składek i należności pochodnych w stosunku do przychodów ogółem oraz stosunkowo rosną pozaskładkowe przychody głównie dotacje oraz wpływy ze składek przekazanych do OFE. Oznacza to większe wydatki państwa w zakresie finansowania świadczeń z FUS 
i w konsekwencji powiększanie deficytu budżetowego. Rosnąca kwota środków budżetowych w przychodach ogółem FUS oznaczają systematyczny wzrost wydatków FUS i niewystarczającą ich rekompensatę z otrzymywanych przez FUS składek i należności pochodnych. Prognoza dotycząca salda rocznego FUS określa powiększający się poziom deficytu tego funduszu: od poziomu 56,3 mld PLN w 2017 roku po kwotę 68,6 mld PLN w 2021 roku [Prognoza wplywów..., 2015: 19].Tabela 4 pokazuje jak systematycznie obniża się poziom wartości indeksu MMGPI dla Polski w ostatnich latach. Pogarsza się przede wszystkim ocena trwałości i adekwatności naszego systemu emerytalnego.

\begin{tabular}{|c|c|c|c|c|}
\hline Rok & Wartość ogólna & Adekwatność & Trwałość & Integralność \\
\hline 2011 & 58,6 & 64,3 & 40,7 & 74,5 \\
\hline 2012 & 58,2 & 63,6 & 43,4 & 70,1 \\
\hline 2013 & 57,9 & 64,4 & 42,6 & 68,9 \\
\hline 2014 & 56,4 & 61,7 & 41,4 & 68,9 \\
\hline 2015 & 56,2 & 61,8 & 40,6 & 69,0 \\
\hline 2016 & 54,4 & 57,9 & 41,2 & 67,3 \\
\hline
\end{tabular}

Tabela 4. Wartość indeksu MMGPI dla Polski w latach 2011-2016 Źródło: www5 (dostęp: 17.11.2016).

Sformułowano dla Polski zalecenia, które pozwoliłyby podnieść (utrzymać) otrzymywaną ocenę na poziomie C [www5]:

- utrzymanie znaczącej roli drugiego filara,

- podniesienie minimalnego poziomu wsparcia dla najuboższych emerytów,

- wprowadzenie wymogu, że część świadczenia emerytalnego z prywatnych systemów emerytalnych należy traktować jako strumień ich dochodów,

- podniesienia poziomu oszczędności gospodarstw domowych,

- zwiększenie poziomu składek, powiększających tym samym poziom aktywów w przyszłości (co jest mało prawdopodobne),

- wzrost współczynnika aktywności zawodowej osób w starszym wieku, w związku ze wzrostem oczekiwanej długości życia, co pozwoliłoby stworzyć ochronę ich dochodów,

- wydłużanie wieku emerytalnego,

- stworzenie odpowiednich zachęt do późniejszego przechodzenia na emeryturę, aby utrzymać jak najdłużej osoby starsze na rynku pracy. Co jest zgodne z wytycznymi Komisji Europejskiej [Biała Ksiega Komisji Europejskiej...]. 


\section{Chilijski system emerytalny}

System chilijski będzie przedmiotem pogłębionej analizy z dwóch powodów. Z jednej strony jest to system, którego założenia i rozwiązania kapitałowe były podstawą wykorzystaną w wielu krajach Ameryki Poł. i Europy Środkowo-Wschodniej podczas tworzeniach ich systemów emerytalnych. Klasyfikowany jest przez lata jako jeden z najlepszych systemów, z bardzo wysoką oceną grupy B, o solidnej konstrukcji, posiadający wiele dobrych cech. Pewne obszary wymagają jednak naprawy, co nie pozwala zakwalifikować sysytemu do grupy A. Z drugiej strony w tym kraju odbywają się wielomilionowe manifestacje osób protestujących przeciwko obowiązującym rozwiązaniom emerytalnym. Można zadać sobie pytanie, które elementy wprowadzonych rozwiązań sprawiają tak wielkie niezadowolenie wśród chilijskiego społeczeństwa? Dlaczego pomimo tak wysokiej oceny w rankingu na najlepszy system emerytalny na świecie nie znajduje on powszechnej akceptacji? Tabela 5 pokazuje wartość indeksu MMGPI za lata: 2015-2016.

\begin{tabular}{|c|c|c|c|c|c|}
\hline Rok & Ocena & Wartość ogólna & Adekwatność & Trwałość & Integralność \\
\hline 2015 & B & 69,1 & 62,8 & 65,0 & 84,8 \\
\hline 2016 & B & 66,4 & 56,5 & 68,4 & 79,6 \\
\hline
\end{tabular}

Tabela 5. Wartość indeksu MMGPI dla Chile w latach 2015-2016

Źródło: www6 (dostęp: 12.01.2017).

Od 2014 roku system w Chile otrzymuje bardzo wysoką ocenę B, a oceniany jest od samego początku istnienia rankingu, a więc od 2009 roku - zaczynając od oceny C. Systematycznie obniża się łączna wartość prezentowanego wskaźnika, a na jej spadek wpływ ma przede wszystkim pogarszająca się ocena adekwatności systemu, na którą wpływ ma niska stopa zastąpienia, bardzo niskie świadczenia. W celu poprawienia sytuacji wprowadzone zostały zalecenia dla chilijskiego systemu: podniesienie poziomu obowiązkowych składek, podniesienie poziomu oszczędności gospodarstw domowych, zwiększenie wieku emerytalnego dla mężczyzn i kobiet, kontynuowanie podtrzymywania minimalnej emerytury dla najbiedniejszych emerytów. Są to zalecenia, które będzie bardzo trudno zrealizować, wydają się bardziej rozważaniami teoretycznymi, nie będą na pewno przyjęte z zadowoleniem przez chilijskie społeczeństwo. 
W 1981 roku w Chile wprowadzono system emerytalny z jedną płaszczyzną kapitałową, który stał się przykładem rozwiązań zastosowanych w innych krajach tego regionu: Argentyny, Meksyku czy też Urugwaju [Kalina-Prasznic 2011]. Dostrzegało się jego główne wady, którymi są: brak konkurencyjności pomiędzy otwartymi funduszami emerytalnymi oraz, do 2008 roku, wysokie opłaty za zarządzanie. Jest to system o zdefiniowanej składce, w którym wysokość emerytury jest uzależniona od zgromadzonego kapitału i dalszej długości trwania życia. Wypłaty świadczeń zaczęły weryfikować wprowadzone rozwiązania. Okazało się, że trzy czwarte osób, które odprowadzały składki emerytalne do prywatnych funduszy emerytalnych nie zdołało oszczędzić na tyle, by otrzymać emeryturę na minimalnym poziomie [Owczarek 2011]. Państwo musiało od początku dopłacać do tych niewielkich świadczeń.

$\mathrm{Z}$ drugiej strony - dane statystyczne pokazują, iż w okresie 35 lat funkcjonowania tego systemu fundusze emerytalne wypracowały wysokie stopy zwrotu, a opłaty zostały radykalnie obniżone, jednakże kryzys finansowy ukazał problemy przed którymi stoją kapitałowe systemy emerytalne [www9]. Zwraca uwagę przede wszystkim niska składka emerytalna, która wynosi $10 \%$ płacy brutto oraz pojawiający się problem ciągłości jej opłacania. Sytuację pogarsza wysokie zróżnicowanie dochodów, które sprawiają, że znaczna część chilijskich emerytów otrzymuje niskie świadczenia emerytalne [Wieprzowski 2015]. Przy tak małych kwotach przekazywanych do funduszy kapitałowych trudno jest zagwarantować wysokie świadczenia w przyszłości. Dane odnoszące się do regionu Ameryki Łacińskiej pokazują, iż osiem z osiemnastu krajów tego obszaru mają stopę zastąpienia poniżej 30\% [Holzmann 2012].

Biorąc pod uwagę powyższe uwarunkowania, można zauważyć, iż powołana Komisja ds. Reformy Systemu Emerytalnego w Chile powinna się skupić na zmianie strukturalnych czynników ograniczających wysokość świadczeń emerytalnych. Można tu wymienić: zmniejszenie szarej (czarnej) strefy związanej z zatrudnianiem, zwiększenie długości i ciągłości okresu odprowadzania składek emerytalnych oraz zwiększenie tempa wzrostu płac. Wszystkie te rozwiązania wymagają odpowiednich reform prowadzących do zwiększenia wydajności pracy. Jednakże nie może to być tylko zwiększenie składki emerytalnej, której wzrost może zwiększyć koszty pracy powodujące spadek poziomu i ciągłości rejestrowanego zatrudnienia. Zwraca się więc uwagę, iż jest to obecnie główny problem wszelkich działań prowadzonych przez instytucje zarządzające funduszami emerytalnymi mających na celu zgromadzenie odpowiednie środki na przyszłe świadczenia w Chile. Musi to zrozumieć chilijskie społeczeństwo. 


\section{Podsumowanie}

Stworzony w 2009 roku The Melbourne Mercer Global Pension Index dokonuje oceny systemów emerytalnych wybranych krajów, biorąc pod uwagę adekwatność, trwałość i integralność. Systemy te różnią się pod względem uwarunkowań historycznych, społecznych, politycznych i gospodarczych, które miały wpływ na ich powstawanie, obecny i przyszły kształt. Mając to na uwadze niemożliwe jest stworzenie idealnego uniwersalnego systemu emerytalnego, jednakże można wskazać odpowiednie cechy, które gwarantowałyby skuteczność wprowadzanych rozwiązań. Na podstawie przeprowadzanych badań firma Mercer wskazuje na takie rozwiązania i na podstawie doświadczeń poszczególnych państw opracowuje szereg zaleceń, które mogłyby ulepszyć systemy emerytalnego innych krajów, poprawić przyszłą sytuację finansową osób pobierających świadczenia emerytalne, a także zwiększyć zainteresowanie prywatnymi programami emerytalnymi. Szczegółowo przeanalizowano systemy emerytalne Polski i Chile, w których płaszczyzna kapitałowa została wprowadzona $\mathrm{w}$ wyniku szerokich reform emerytalnych $\mathrm{w}$ latach 80. ubiegłego wieku.

Zalecenia w obszarze adekwatności dotyczą: minimalnej emerytury skierowanej dla osób najuboższych, stopy zastąpienia, która ma wynosić $70 \%$ dochodów netto osoby pracującej na pełnym etacie. W zakresie trwałości zaleca się, między innymi - aby co najmniej 70\% ludzi w wieku produkcyjnym korzystała z prywatnych programów emerytalnych, aktywa emerytalne przekraczały $100 \%$ PKB. Utrzymanie odpowiedniego poziomu integralności można poprzez nadzór ostrożnościowy nad prywatnymi programami emerytalnymi, zachowanie odpowiednich relacji i utrzymywanie regularnej komunikacji z członkami programów, kontrolę klauzul, punktualną prezentację raportów, jasną definicję pobieranej składki, jak i przyszłych świadczeń.

\section{Bibliografia}

Analiza 2/2015: Sukces chilijskiego systemu emerytalnego a popularne mity. Wnioski dla Polski, https://for.org.pl/pl/a/3449,Analiza-FOR-22015-Sukces-chilijskiego-systemu-emerytalnego-a-popularne-mity-Wnioski-dla-Polski. 
Biała Księga Komisji Europejskiej. Plan na rzecz adekwatnych, bezpiecznych i stabilnych emerytur (2012), http://ec.europa.eu/social/BlobServlet?docld=7341\&langld=pl.

Holzmann R. (2012), Global Pension Systems and Their Reform: Worldwide Drivers, Trends, and Challenges.

Kalina-Prasznic U. (2011), Systemy emerytalne w warunkach kryzysów - między państwem a rynkiem, [w:] J. Kunder (red.), Globalizacja, europejska integracja a kryzys gospodarczy, Prace Naukowe Wydziału Prawa, Administracji, Ekonomii Uniwersytetu Wrocławskiego, Wrocław.

Mercer rekomenduje system kapitałowy i podkreśla znaczenie Il filara (2016), Izba Gospodarcza Towarzystw Emerytalnych, Warszawa.

Nowak K., Sucharski N. (2015), Wybrane aspekty działalności otwartych funduszy emerytalnych, Mercer, Warszawa.

Owczarek J. (2011), Druga fala reform emerytalnych w świetle zmodyfikowanej wielofilarowej koncepcji Banku Światowego, ,"Rozprawy Ubezpieczeniowe” , nr 10.

Prognoza wpływów i wydatków Funduszu Ubezpieczeń Społecznych na lata 2017-2021 (2015), Departament Statystyki i Prognoz Aktuarialnych ZUS, Warszawa.

Wieprzowski P. (2015), Czy chilijska reforma emerytalna była rzeczywiście nieudana?, http://www.forbes.pl/chilijski-system-emerytalny-wnioski-dla-polski,artykuly, 196688,1,1.html.

[www1] http://finanse.wp.pl/gid,15767229,kat,1033803,title,Najlepsze-systemy-emerytalne-swiata-i-Polska,galeria.html (dostęp: 12.04.2016).

[www2] http://finanse.wp.pl/gid,16194095,kat,36874,title,Ranking-systemow-emery talnych-2013,galeria.html?ticaid=116cbd (dostęp: 10.04.2016).

[www3] https://pdfs.semanticscholar.org/9a43/829ebae672083d8fa6882509631896 b39e7a.pdf.

[www4] http://www.bibliotekacyfrowa.pl/Content/35534/031.pdf.

[www5] http://www.globalpensionindex.com/country-summaries-2/poland/ (dostęp: 17.11.2016).

[www6] https://www.mercer.com/content/dam/mercer/attachments/global/Retirement/ gl-2016-mmgpi-impact-ageing-populations-full-report.pdf (dostęp: 12.01.2017).

[www7] http://www.mercer.com/our-thinking/mercer-melbourne-global-pensionindex.html (dostęp: 17.11.2016).

[www8] http://www.rp.pl/artykul/945257-Dunski-system-emerytalny-najwyzej-oceniony.html\#ap-1 (dostęp: 10.04.2016).

[www9] www.zus.pl/default.asp?p=1\&id=1\&idk=1149 (dostęp: 14.01.2017).

\section{RANKING ŚWIATOWYCH SYSTEMÓW EMERYTALNYCH WEDŁUG MELBOURNE MERCER GLOBAL PENSION INDEX}

Systemy emerytalne na całym świecie znajdują się obecnie pod wielką presją. Niebezpieczeństwa dotyczą przede wszystkim czynników demograficznych. Zwraca się uwagę na szybkie starzenie się społeczeństwa, a więc wydłużanie 
się statystycznej długości życia, niskie wskaźniki dzietności, zjawiska falowania demograficznego. Wielki wpływ mają także czynniki ekonomiczne, a wśród nich wzrost długu publicznego, duże bezrobocie wśród młodych osób, obniżające się tempo wzrostu gospodarczego. Wielkie wyzwania stają przed publicznymi systemami emerytalnymi zapewniającymi niezbędne świadczenia osobom kończącym aktywność zawodową. Stworzony przez australijską firmę doradczą Mercer, przy współpracy z Australijskim Centrum Badań Finansowych (ACFS) - Światowy Indeks Emerytalny (The Melbourne Mercer Global Pension Index) mierzy 27 systemów emerytalnych z całego świata, obejmując $60 \%$ światowej populacji. Pozwala ocenić zmiany zachodzące w publicznych systemach emerytalnych, a przy tym uchwycić pozytywne i negatywne działania w nich zachodzące. Ranking przedstawia przy tym niezbędne zalecenia naprawcze usprawniające czy też likwidujące pojawiające się nieprawidłowości.

Słowa kluczowe: system emerytalny, otwarte fundusze emerytalne, świadczenia emerytalne, Światowy Indeks Emerytalny.

\section{RANKING THE WORLD'S PENSION SYSTEMS ACCORDING TO THE MELBOURNE MERCER GLOBAL PENSION INDEX}

Pension schemes around the world are currently under great pressure. Dangers that they are facing revolve primarily around demographic factors. Special attention has to be paid to the rapid ageing of the population, which is connected to the lengthening of the statistical life expectancy and low fertility rates. Economic factors, such as the increase in public debt, high unemployment among young people and declining economic growth have to be considered. Great challenges are looming in the near future for the public pension systems that might stand in the way of providing necessary benefits to people beyond their economic activity. Created by the Australian consulting firm Mercer, in collaboration with the Australian Centre for Financial Research (ACFs) - Global Pension Index (The Melbourne Mercer Global Pension Index) measures a selection of 27 pension systems around the world that cover $60 \%$ of the world population. It allows to evaluate changes in the public pension systems and at the same time registers positive and negative activities taking place within them. Furthermore it presents necessary remedial recommendations to streamline occurring irregularities.

Keywords: social security, pension system, open pension funds, retirement benefits, Global Pension Index. 